\title{
The Alternative Use of Water Hyacinth and Reed as Attached Growth of Microbial in Waste Water Treatment
}

\author{
H. Purnobasuki ${ }^{1}$, N.I. Oktavitri ${ }^{1}$, T. Nurhayati ${ }^{1}$, B. Saadah ${ }^{1}$, Rafsanjani S.I ${ }^{1}$
}

\begin{abstract}
Aquatic plants have ability to decrease of waste water contaminant. The Water Hyacinth (Eichornia crassipes) and Reed (Imperata cylindrical) are aquatic plants which have ability to reduce concentration of BOD, TSS, COD, Total Nitrate and Total Phosphate in wetland. The other side, it can be used for media support in anaerobic treatment. Because of their abilities, there is some possibilities that Water Hyacinth and Reed can be used as attached growth of microorganisms. The aims of this study was to investigate the potential of water hyacinth and reed as attached media of microbe growth. Part of the plants are used is the trunk part. A slices of trunk is $1 \mathrm{~cm}$. The analysis were conducted for 14 days with ratio $60 \%$ waste water and $40 \%$ air of reactor. Results of this study for water hyacinth that TSS decrease up to 71\%. COD and Total Phosphate decrease $60 \%$, Total Nitrate decrease $85 \%$. While, for reed, TSS decrease up to 41\%. COD decrease 56\%, Total Phosphate decrease $41 \%$. Total Nitrate decrease $10 \%$. In conclusion, both of them had a potential as attached media of microbe growth. But, Water Hyacinth was better as media support than reed.
\end{abstract}

Keywords - Attached, Decrease, Growth, Reed, Water Hyacinth.

\section{INTRODUCTION}

$\mathrm{O}$ ne of type of domestic wastewater is canteen wastewater. Canteen wastewater produces from washing dishes. Canteen wastewater, household wastewater, restaurant wastewater has highly organic substance (Apriyadi, 2008). In other side, the high organic substance can influence aquatic biota. Therefore it need to be treated canteen wastewater..

Wetland treatments system can decrease highly organic substance. Wetland water treatment use aquatic plants. Aquatic plants which usually uses wetland system are Eichhorniacrassipesand Imperataclindrycal. E. crassipesand I. clindrycal have cellulose which supported growth of microba. I. clindrycal has 58,62\% of cellulose (Sutiya et al, 2012) and E. crassipeshas $64,51 \%$ of cellulose (Kriswiyanti and RD, 2009). The other side, cellulose used of microorganism for nutrition which degradation organic substance. The nutrition is one of important characteristic in the processing of wastewater, although the required is less nutrition. The kinds nutrition which added to wastewater treatment can from fertilizer, such us NPK (Paramita, 2012). But, the used of fertilizer need more investastation cost than $\mathrm{E}$. crassipesand I. clindrycal.

The added of E. crassipesand I. clindrycal in wastewater treatment as packed media. The added of packed media can increase organic substance removal, especially COD (Chemichal Oxygen Demand) and BOD (Biochemical Oxygen Demand). The competency of anaerobic reactor added with packed media reached COD removal 76-86\%, and BOD removal 70-91\% (Banu et al, 2007). Banu et al (2007) said that supported material helped growth of biofilm. Biofilm adhered on packed media has used in that reactors. Most of reactors used packed media for treated wastewater by attached growth was more effective than suspended growth.

${ }^{1}$ H. Purnobasuki, N.I. Oktavitri, T. Nurhayati, B. Saadah, Rafsanjani S.I are with Departement of Biology, Faculty of Environmental Sains and Technology, Universitas Airlangga, Surabaya, Indonesia. E-mail: herypurba@yahoo.com; nur_i_d_o@yahoo.com.
Many research use anorganic material as packed media (Banu et al, 2007 and Syafila et al, 2003). There is a lack of research use organic material as packed media and as supported nutrition for degradation organic substance. This research aims is to investigate the potential of water hyacinth and reed as attached media of microbe growth. The E. crassipesand I. clindrycal as attached media use for decreasing COD and BOD which added total $\mathrm{N}$ and total P.

\section{METHOD}

Wastewater used in this research from canteen at Sciency and Technology Faculty, Airlangga University Surabaya, JawaTimur. The canteen wastewater was collected from fresh canteen wastewater without any preliminary treatment. The than E. crassipesand I. clindrycal which used with specific characterictic.

The reactor volume was 1 liter and 30\% of reactor volume was used as packed media. Ractor was made from LDPE with height $30 \mathrm{~cm}$ and diameter $10 \mathrm{~cm}$. The system of this anaerobic reactor was batch system. There were two steps of this reactor: first step studied ability of Imperata cylindrical and Eichhornia crassipes which had highest removal efficiency (with the same height: $1 \mathrm{~cm}$ ); the second step was studied the best specific size $(1 \mathrm{~cm}$ or $2 \mathrm{~cm}$ ) for used from media which chosen in first step.

Parameters had observed in this research were COD; BOD; TSS; VSS; pH; suhu; NO3; Methods used based on standard methods. Wastewater incubated in 7 days, paremeters investigated before and after incubation.

\section{RESULT AND DISCUSSION}

Reactor used was a batch system. Whereas doesn't need oxygen in the process of wastewater degradation. Media used are trunk of the plant. Trunk of E. Crassipe and I. cylindrical cut approximately $1 \mathrm{~cm}$. The ratio of the loaded media is $60 \%$ wastewater and $40 \%$ of air. Analyses were performed with a 14-day incubation period.

The addition of media is influent to decreased value of COD, TSS, VSS, total $\mathrm{N}$ and total P. The content of cellulose in the E. Crassipe and I. cylindrical was 
important nutrients for microorganism. It increased the ability of Decreased of TSS was higher in waste water hyacinth added compared to reed added. Water hyacinth surface area was larger than the reeds, so that the water hyacinth underneath the reactor and causing microbes attached to them, while reeds will float on the surface of the reactor. This resulted in the growth of microbes to degrade more waste was found in the water hyacinthmicroorganisms to degrade organic substance in canteen waste water. Cellulose content of E. Crassipe is higher than I. cylindrical, so E. Crassipe removal percentage is greater than I. cylindrical. This causes the microbes are attached to the E. Crassipe media more if compared with I. cylindrical and without media.

Experiment were performed for incubation 14 days. The results showed that after incubation 14 days, COD decreased from $1000 \mathrm{mg} / \mathrm{L}$ to $1992 \mathrm{mg} / \mathrm{L}$ for wastewater; $3984 \mathrm{mg} / \mathrm{L}$ for wastewater added E.crassipe; $4316 \mathrm{mg} / \mathrm{L}$ for wastewater added I. cylindrical. The removal of TSS and VSS had the same thing, after 14 days incubation TSS decrease from $860 \mathrm{mg} / \mathrm{L}$ to $570 \mathrm{mg} / \mathrm{L}$ for only waste water. The other side, additional media can decrease TSS from $860 \mathrm{mg} / \mathrm{L}$ to $245 \mathrm{mg} / \mathrm{L}$ with E.crassipe.

The result in in figure 2 showed that after incubation 14 days, VSS increased from 453,3 mg/L to $483,3 \mathrm{mg} / \mathrm{L}$ for wastewater; VSS decreased 453,33 $\mathrm{mg} / \mathrm{L}$ to 238,3 $\mathrm{mg} / \mathrm{L}$ for wastewater added E. Crassipe,: VSS decreased $453,33 \mathrm{mg} / \mathrm{L}$ to $178,33 \mathrm{mg} / \mathrm{L}$ for wastewater added I. cylindrical.

Addition of media could entrapped suspended solid in the bottom of reactor. The entrapped particle could decreased of TSS. The decreasing of TSS effect of decreasing of VSS. TSS contain VSS around $70-80 \%$. Decreasing of COD and TSS followed by decreasing of nitrate (NO3) and Phosphat (PO4). Nitrate and phosphate are makro nutrient that used for energy to decreasing of COD and TSS. Figure 3, showed that Nitrate form 4,31 $\mathrm{mg} / \mathrm{L}$ decreasing to $0,31 \mathrm{mg} / \mathrm{L}$ after incubation COD.

\section{CONCLUSION}

The addition of E. Crassipe as attached media can decrease COD until 60\%, TSS 71.5\%, NO3 85.4\%, PO4 $58 \%$. While the addition of I. cylindrical as attached media can reduce $56.84 \%$ of COD, TSS $41.27 \%$, NO3 $9.95 \%$, PO4 41.2\%. In conclusion, both of them had a potential as attached media of microbe growth. But, Water Hyacinth was better as media support than reed.

\section{ACKNOWLEDGEMENT}

This research was funded with DIPA Airlangga University 2013 with number contract 001/UN3.6/KR\U/PPK/2013, 2 May 2013. Numbered Letter of Rector Airlangga University 7673/UN3/KR/2013 (2 May 2013). This research was supported with solid team: Deavy Trianingtyas; Bidayatus Saadah; Fandi Nufinda Rahman; Hairul Amin; Adelia Anju Asmara; Santini Ika R.; Rosvita Tri J.; Sofiyudin; Defananda..

\section{REFERENCES}

[1]. Apriadi, Tri, "Kombinasi Bakteri danTumbuhan Air Sebagai Bioremediator Dalam Mereduksi Kandungan Bahan Organic LimbahKantin”, Fakultas Perikanan dan Ilmu Kelautan, IPB, 2008, pp. 1-2.

[2]. [2] de Lemos Chernicaro, C. A. 2007. Anaerobic Reactors. IWA Publishing. New York. 70-82

[3]. [3] Gerardi, M. H. The Microbiology of Anaerobic Digester. Wiley Interscience. United States of America. 77-177

[4]. [4] Paramita P., M.Shovitri, dan N. D. Kuswytasari, "Biodegradasi Limbah Organik Pasar dengan Menggunakan Mikroorganisme Alami Tangki Septik”, J. Sains dan Seni ITS, 2012, Vol. 1, pp. 23-26.

[5]. [5] Banu, J. R.; Kuliappan, S.; Yeom, I. T. (2007). Treatment of Domestic Wastewater Using Upflow Anaerobic Sludge Blanket Reactor. Int. J. Environ. Sci., 4(3), 363-370.

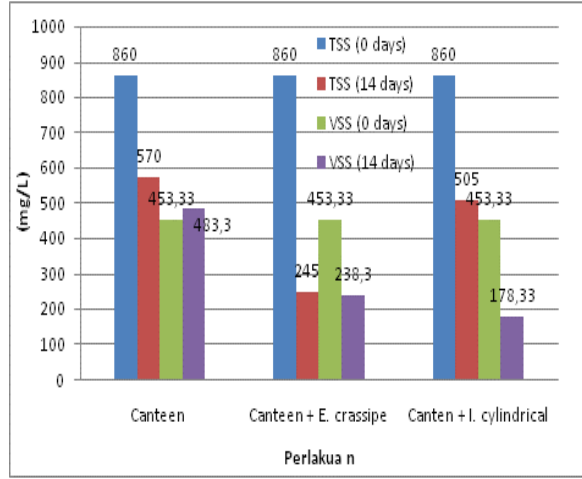

(a)

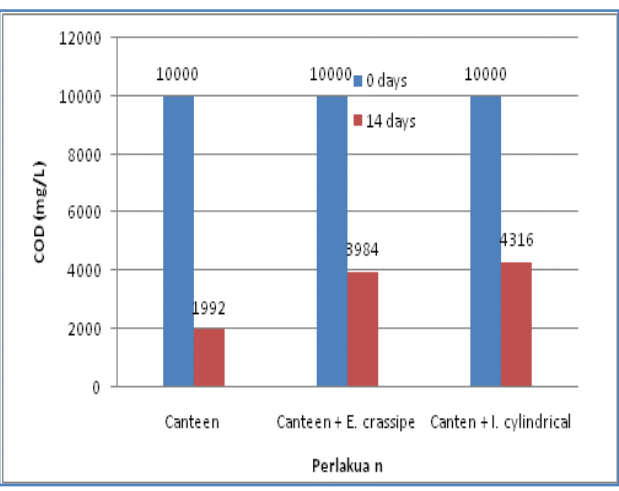

(b)

Figure 1. (a) The value of TSS (Total Suspended Solid) and VSS (Volatil Suspended Solid) removal (b) The value of COD (Chemical Oxygen Demand) removal 


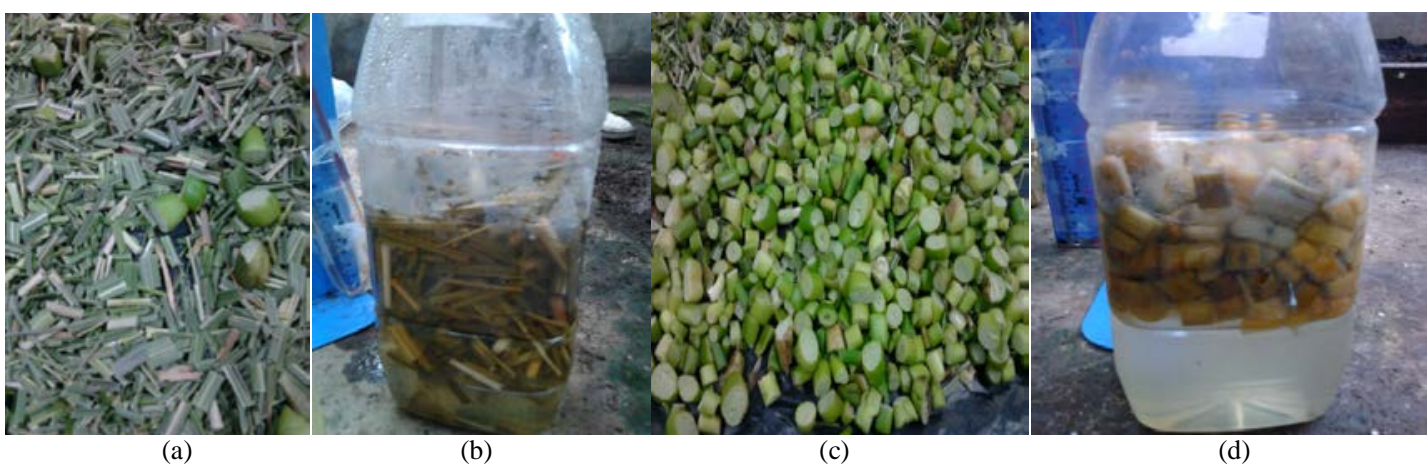

Figure 2. (a) I. cylindrical cutting along $1 \mathrm{~cm}$ (b) I. cylindrical as attached media in reactor (c) E.crassipe cutting along $1 \mathrm{~cm}$ (d) E.crassipe as attached mediain reactor

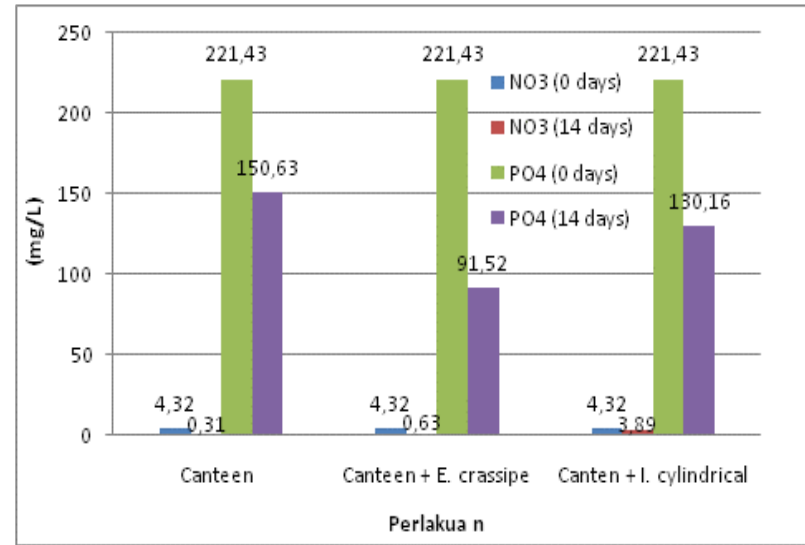

Figure 1. The Value of NO3 and PO4 removal 